\title{
Study on Spectrophotometric Determination of Trace Copper after Flotation Separation using Sodium Chloride-Ammonium Thiocyanate-Dodecyl Dimethyl Benzyl Ammonium Chloride System
}

\author{
Changqing $\mathrm{Tu}^{\mathrm{a}}$, Xinrong Wen ${ }^{\mathrm{b}}$ \\ College of Chemistry and Environment,Jiaying University,Meizhou,Guangdong 514015,China \\ atcq@jyu.edu.cn, bwxrong5093@hotmail.com
}

Keywords:copper; flotation separation; ammonium thiocyanate; dodecyl dimethyl benzyl ammonium chloride; environmental water samples

\begin{abstract}
The paper presents a novel method for the spectrophotometric determination of trace $\mathrm{Cu}^{2+}$ after flotation separation using sodium chloride-ammonium thiocyanate-dodecyl dimethyl benzyl ammonium chloride system. The effects of the dosages of $\mathrm{NH}_{4} \mathrm{SCN}$ and dodecyl dimethyl benzyl ammonium chloride (DDBAC),various salts and acidity etc. on the flotation yield of $\mathrm{Cu}^{2+}$ have been investigated. The possible flotation separation mechanism of $\mathrm{Cu}^{2+}$ was discussed.The results showed that by controlling $\mathrm{pH} 4.0$, in NaCl-NH $\mathrm{SCN}_{4} \mathrm{SCDBC}$ system, the water-insoluble ternary association complex of $(\mathrm{DDBAC})_{2}\left[\mathrm{Cu}(\mathrm{SCN})_{4}\right]$ which produced by $\mathrm{Cu}^{2+}$ and $\mathrm{SCN}^{-}, \mathrm{DDBAC}$ cation $\left(\mathrm{DDBAC}^{+}\right.$) floated above water phase and liquid-solid phases were formed with clear interface, while $\mathrm{Mn}^{2+}, \mathrm{Ni}^{2+}, \mathrm{Fe}^{2+}$ and $\mathrm{Al}^{3+}$ could not be floated,so $\mathrm{Cu}^{2+}$ was floated quantitatively. Thereby, the quantitative separation of $\mathrm{Cu}^{2+}$ from the above metal ions could be achieved. A new spectrophotometric method of determination of trace copper by flotation separation was established.The proposed method has been successfully applied to the determination of $\mathrm{Cu}^{2+}$ in various environmental water samples with satisfactory results.
\end{abstract}

\section{Introduction}

Copper is one of the essential microelements for human.Copper deficiency leads to serious medical diseases.However,at higher than normal levels,it turns out to be harmful to the human body,ingesting excessive copper can cause vomiting, nausea, diarrhea, liver or kidney damage or even death. It has been found that copper can accumulate in surface waters.Consequently,it is of great importance and significance for life science to determinate trace copper in environmental samples.Since the content of $\mathrm{Cu}^{2+}$ in environment is usually very low, separation and enrichment must be carried out before measurement.There are many other methods to separate and enrich $\mathrm{Cu}(\mathrm{II})$,such as solvent extraction ${ }^{[1-3]}$, cloud point extraction ${ }^{[4-5]}$, activated carbon absorption ${ }^{[6]}$, liquid membrane extraction ${ }^{[7-8]}$,ion-exchange resin separation ${ }^{[9]}$,HPLC separation ${ }^{[10]}$, ultrasound-assisted extraction ${ }^{[11]}$, solid-phase extraction ${ }^{[12-13]}$.

In this paper we have studied the spectrophotometric determination of trace $\mathrm{Cu}^{2+}$ after flotation separation using sodium chloride- ammonium thiocyanate-dodecyl dimethyl benzyl ammonium chloride system. by controlling $\mathrm{pH} 4.0$, in the presence of $1.0 \mathrm{~g} \mathrm{NaCl}$, when the dosage of $0.10 \mathrm{~mol} / \mathrm{L} \mathrm{NH}_{4} \mathrm{SCN}$ was $3.00 \mathrm{~mL}$ and $0.010 \mathrm{~mol} / \mathrm{L}$ DDBAC solution was $2.50 \mathrm{~mL}$ respectively, the water-insoluble ternary association complex of $(\mathrm{DDBAC})_{2}\left[\mathrm{Cu}(\mathrm{SCN})_{4}\right]$ which produced by $\mathrm{Cu}^{2+}$ and $\mathrm{SCN}^{-}, \mathrm{DDBAC}^{+}$floated above water phase and liquid-solid phases were formed with clear interface, while $\mathrm{Mn}^{2+}, \mathrm{Ni}^{2+}, \mathrm{Fe}^{2+}$ and $\mathrm{Al}^{3+}$ could not be floated,so $\mathrm{Cu}^{2+}$ was floated quantitatively. Thereby, the quantitative separation of $\mathrm{Cu}^{2+}$ from the above metal ions could be achieved. A new spectrophotometric method of determination of trace copper by flotation separation using sodium chloride-ammonium thiocyanate-dodecyl dimethyl 
benzyl ammonium chloride system was established.The proposed method has been successfully applied to the determination of $\mathrm{Cu}^{2+}$ in various environmental water samples with satisfactory results.

\section{Experiment}

\section{Equipment and reagents}

A model 722S spectrophotometer (Shanghai No.3 Analysis Equipment Plant) was used for photometric measurements.

$\mathrm{NH}_{4} \mathrm{SCN}$ solution:0.10 $\mathrm{mol} \cdot \mathrm{L}^{-1}$. Borax solution: $0.1 \mathrm{~mol} \cdot \mathrm{L}^{-1}$. Dodecyl dimethyl benzyl ammonium chloride: $0.010 \mathrm{~mol} \cdot \mathrm{L}^{-1} .1 .0 \times 10^{-3} \mathrm{~mol} \cdot \mathrm{L}^{-1}$ of 4 -(2-pyridylazo) resorcinol (PAR) ethanol solution was prepared by dissolving $0.1076 \mathrm{~g}$ PAR in $500 \mathrm{~mL}$ of ethanol solution. A stock of standard solution of $\mathrm{Cu}^{2+}$ : $1.000 \mathrm{~g} \cdot \mathrm{L}^{-1}$.A working standard solution was prepared by appropriately diluting the stock standard solution. Standard solution of other metal ions was prepared by appropriately diluting the stock standard solution.Buffer solutions of different $\mathrm{pH}$ was prepared as references[14].

All reagents were of analytical reagent grade.Bidistilled water was used throughout.

\section{Method}

$50 \mu \mathrm{g}$ of $\mathrm{Cu}^{2+}$, a given amounts of $0.10 \mathrm{~mol} \cdot \mathrm{L}^{-1} \mathrm{NH}_{4} \mathrm{SCN}$ solution and $0.010 \mathrm{~mol} \cdot \mathrm{L}^{-1}$ DDBAC solution were added into a $25 \mathrm{~mL}$ ground color comparison tube,then dilute the mixture to $10.00 \mathrm{~mL}$ with $\mathrm{pH} 4.0$ buffer solution.1.0 $\mathrm{g} \mathrm{NaCl}$ was added and shaken adequately and they were kept still for a moment.1.00 $\mathrm{mL}$ of salt water sample in the lower layer was transferred into another $25 \mathrm{~mL}$ ground color comparison tube, and $1.5 \mathrm{~mL}$ of $1.0 \times 10^{-3} \mathrm{~mol} \cdot \mathrm{L}^{-1} \mathrm{PAR}$ ethanol solution and $3.0 \mathrm{~mL}$ of $0.1 \mathrm{~mol} \cdot \mathrm{L}^{-1}$ borax solution was added.The solution was diluted to the mark and the absorbance was measured at $510 \mathrm{~nm}$ against the reagent blank prepared in the same way. The amount of $\mathrm{Cu}^{2+}$ remained in the solution was calculated and the flotation yield of $\mathrm{Cu}^{2+}(\mathrm{E} / \%)$ was calculated according to the determination results. Photometric analysis of other metal ions was referring the reference[15].

\section{Results and Discussions}

\section{Effect of DDBAC dosage on the flotation yield of $\mathrm{Cu}^{2+}$}

In order to investigate the effect of DDBAC dosage on the flotation yield of $\mathrm{Cu}^{2+}, 50 \mu \mathrm{g}$ of $\mathrm{Cu}^{2+}, 3.00 \mathrm{~mL}$ of $0.10 \mathrm{~mol} \cdot \mathrm{L}^{-1} \mathrm{NH}_{4} \mathrm{SCN}$ solution were applied to the proposed method. It was found that the flotation yield of $\mathrm{Cu}^{2+}$ was zero in the absence of DDBAC in the solution. With the increase of DDBAC dosage, the flotation yield of $\mathrm{Cu}^{2+}$ increased. When the dosage of DDBAC is up to $2.50 \mathrm{~mL}$ or more, the flotation yield of $\mathrm{Cu}^{2+}$ was $100 \%$. Hence, $2.50 \mathrm{~mL}$ of DDBAC was selected for all further studies.

\section{Effect of $\mathrm{NH}_{4} \mathrm{SCN}$ dosage on the flotation yield of $\mathrm{Cu}^{2+}$}

In order to investigate the effect of $\mathrm{NH}_{4} \mathrm{SCN}$ dosage on the flotation yield of $\mathrm{Cu}^{2+}, 50 \mu \mathrm{g}$ of $\mathrm{Cu}^{2+}, 2.50 \mathrm{~mL}$ of $0.010 \mathrm{~mol} \cdot \mathrm{L}^{-1} \mathrm{DDBAC}$ solution were applied to the proposed method.The results showed that the flotation yield of $\mathrm{Cu}^{2+}$ was zero in the absence of $\mathrm{NH}_{4} \mathrm{SCN}$ in the solution. The flotation yield of $\mathrm{Cu}^{2+}$ increased with the increase of $\mathrm{NH}_{4} \mathrm{SCN}$ dosage. When the dosage of $\mathrm{NH}_{4} \mathrm{SCN}$ was up to $3.00 \mathrm{~mL}$ or more, the flotation yield of $\mathrm{Cu}^{2+}$ was $100 \%$. So,3.00 $\mathrm{mL}$ of $\mathrm{NH}_{4} \mathrm{SCN}$ was chosen for subsequent studies.

\section{Flotation separation mechanism}

Based on the results above,only in the simultaneous presence of $\mathrm{NH}_{4} \mathrm{SCN}$ and DDBAC in the solution,can $\mathrm{Cu}^{2+}$ be completed floated.Therefore,the flotation separation mechanism of $\mathrm{Cu}^{2+}$ is as follows: 
(1) $\mathrm{Cu}^{2+}$ reacts with $\mathrm{SCN}^{-}$to form $\mathrm{Cu}(\mathrm{SCN})_{4}{ }^{2-}$.

$$
\mathrm{Cu}^{2+}+4 \mathrm{SCN}^{-} \rightarrow\left[\mathrm{Cu}(\mathrm{SCN})_{4}\right]^{2-}
$$

(Water phase) (Water phase)

(2) $\mathrm{Cu}(\mathrm{SCN})_{4}^{2-}$ reacts with $\mathrm{DDBAC}^{+}$to form the water-insoluble ternary association complex of $(\mathrm{DDBAC})_{2}\left[\mathrm{Cu}(\mathrm{SCN})_{4}\right]$, so $\mathrm{Cu}^{2+}$ was floated quantitatively.

$$
\left[\mathrm{Cu}(\mathrm{SCN})_{4}\right]^{2-}+2 \mathrm{DDBAC}^{+} \rightarrow(\mathrm{DDBAC})_{2}\left[\mathrm{Cu}(\mathrm{SCN})_{4}\right]
$$

$$
\text { (Water phase) (Flotation phase) }
$$

\section{Effect of various salts on the flotation yield of $\mathrm{Cu}^{2+}$}

The effects of $\mathrm{NaCl}, \mathrm{KNO}_{3},\left(\mathrm{NH}_{4}\right)_{2} \mathrm{SO}_{4}$ and $\mathrm{NaBr}$ on liquid-solid divarication and the flotation yield of $\mathrm{Cu}^{2+}$ were investigated.The results showed that liquid-solid divarication could be realized at the presence of each of four salts above. $\mathrm{KNO}_{3},\left(\mathrm{NH}_{4}\right)_{2} \mathrm{SO}_{4}$ and $\mathrm{NaBr}$ decreased the flotation yield of $\mathrm{Cu}^{2+}$ in a certain extent. The presence of $\mathrm{NaCl}$ speeded up liquid-solid divarication and made the interface more clear between two phases, and consequently $\mathrm{Cu}^{2+}$ could be separated quickly and completely. When $\mathrm{NaCl}$ dosage was in $0.5 \mathrm{~g}, 1.0 \mathrm{~g}, 1.5 \mathrm{~g}$, the flotation yields of $\mathrm{Cu}^{2+}$ were $95.1 \%, 100 \%, 100 \%$. When $1.0 \mathrm{~g} \mathrm{NaCl}$ was added, it could make liquid-solid phase separation perfectly.Therefore, $1.0 \mathrm{~g} \mathrm{NaCl}$ was chosen in the further studies.

\section{Effect of pH on the flotation yield of different metal ions}

Under the optimum conditions,the effects of $\mathrm{pH}$ on the flotation yield of different metal ions were investigated.The results showed that in the $\mathrm{pH}$ range $1.0 \sim 7.0$, the flotation yield of $\mathrm{Cu}^{2+}$ was in the range of $95.7 \% \sim 100 \%$, it could be considered that $\mathrm{Cu}^{2+}$ was floated completely. At $\mathrm{pH} 4.0$, the flotation yield of $\mathrm{Mn}^{2+}, \mathrm{Ni}^{2+}, \mathrm{Fe}^{2+}$ and $\mathrm{Al}^{3+}$ were zero or lesser(all less then 5.0\%). Therefore, $\mathrm{Cu}^{2+}$ can be separated from $\mathrm{Mn}^{2+}, \mathrm{Ni}^{2+}, \mathrm{Fe}^{2+}$ and $\mathrm{Al}^{3+}$ in the solution by controlling $\mathrm{pH} 4.0$.

\section{Separation experiments}

Under the chosen conditions, the separations of $\mathrm{Cu}^{2+}$ from $\mathrm{Mn}^{2+}, \mathrm{Ni}^{2+}, \mathrm{Fe}^{2+}$ and $\mathrm{Al}^{3+}$ in synthesized samples of binary and polybasic system were studied respectively. The results were shown in Table 1 and Table 2.

Table 1. The separation results of binary-mixed ions $(\mathrm{pH}=4.0)$

\begin{tabular}{ccccccc}
\hline Mixed ions & \multicolumn{2}{c}{ Metal ions added $(\mu \mathrm{g})$} & \multicolumn{2}{c}{ Metal ions found in water phase $(\mu \mathrm{g})$} & \multicolumn{2}{c}{ Flotation yield(E/\%) } \\
& $\mathrm{Cu}$ & $\mathrm{Me}$ & $\mathrm{Cu}$ & $\mathrm{Me}$ & $\mathrm{Cu}$ & $\mathrm{Me}$ \\
\hline $\mathrm{Cu}^{2+}-\mathrm{Mn}^{2+}$ & 50 & 100 & 0.1 & 104.7 & 99.8 & -4.7 \\
& 50 & 200 & 0 & 197.2 & 100 & 1.4 \\
& 50 & 500 & 0.2 & 493.9 & 99.6 & 1.2 \\
$\mathrm{Cu}^{2+}-\mathrm{Ni}^{2+}$ & 50 & 100 & 0 & 97.4 & 100 & 2.6 \\
& 50 & 200 & 0.2 & 198.4 & 99.6 & 0.8 \\
& 50 & 500 & 0.3 & 491.3 & 99.4 & 1.7 \\
$\mathrm{Cu}^{2+}-\mathrm{Fe}^{2+}$ & 50 & 100 & 0.2 & 100.0 & 99.6 & 0.0 \\
& 50 & 200 & 0.2 & 187.7 & 99.6 & 6.2 \\
& 50 & 500 & 0 & 455.1 & 100 & 9.0 \\
$\mathrm{Cu}^{2+}-\mathrm{Al}^{3+}$ & 50 & 100 & 0.1 & 98.3 & 99.8 & 1.7 \\
& 50 & 200 & 0.2 & 187.6 & 99.6 & 6.2 \\
& 50 & 500 & 0 & 470.2 & 100 & 6.0 \\
\hline
\end{tabular}

Me represents other metal ions except $\mathrm{Cu}^{2+}$. 
Table 2. Separation results of $\mathrm{Cu}^{2+}$ from polybasic-mixed ions $(\mathrm{pH}=4.0)$

\begin{tabular}{lccc}
\hline Number of the synthesized samples & 1 & 2 & 3 \\
\hline Dosage of $\mathrm{Cu}^{2+}(\mu \mathrm{g})$ & 100.0 & 150.0 & 200.0 \\
Dosage of $\mathrm{Me}(\mu \mathrm{g})$ & 50.0 & 100.0 & 200.0 \\
$\mathrm{Cu}^{2+}$ found in solid phase $(\mu \mathrm{g})$ & 96.8 & 143.1 & 196.2 \\
Flotation yield of $\mathrm{Cu}^{2+}(\mathrm{E} / \%)$ & 96.8 & 95.4 & 98.1 \\
\hline
\end{tabular}

Me represents $\mathrm{Mn}^{2+}, \mathrm{Ni}^{2+}, \mathrm{Fe}^{2+}$ and $\mathrm{Al}^{3+}$.

\section{Determination of $\mathrm{Cu}^{2+}$ in various environmental water samples}

$500 \mathrm{~mL}$ environmental water sample was heated,cooled and filtered to remove insolution suspended substance. Then $\mathrm{pH}$ was adjusted to 4.0 with buffer solution. $12.00 \mathrm{~mL}$ of $0.10 \mathrm{~mol} \cdot \mathrm{L}^{-1} \mathrm{NH}_{4} \mathrm{SCN}$ solution, $10.00 \mathrm{~mL}$ of $0.010 \mathrm{~mol} \cdot \mathrm{L}^{-1} \mathrm{DDBAC}$ solution were added into the solution.Aftering stiring for $20 \mathrm{~min}$, the content of $\mathrm{Cu}^{2+}$ in filtrate was determined by GFAAS method.Meanwhile, the recovery test of standard addition was performed. The recovery yield of $\mathrm{Cu}^{2+}(\mathrm{E} / \%)$ was calculated. The results were showed in Table 3.

\begin{tabular}{ccccccc} 
Table 3. & The determination results of $\mathbf{C u}^{2+}$ in various environmental water sample $(\mathbf{p H}=\mathbf{4 . 0})$ \\
\hline Sample & $\begin{array}{c}\mathrm{Cu}^{2+} \text { added } \\
\left(\mu \mathrm{g} \cdot \mathrm{L}^{-1}\right)\end{array}$ & $\begin{array}{c}\mathrm{Cu}^{2+} \text { found in } \\
\text { filtrate }\left(\mu \mathrm{g} \cdot \mathrm{L}^{-1}\right)\end{array}$ & $\begin{array}{c}\mathrm{Cu}^{2+} \text { found in solid } \\
\mathrm{phase}\left(\mu \mathrm{g} \cdot \mathrm{L}^{-1}\right)\end{array}$ & $\begin{array}{c}\mathrm{Cu}^{2+} \text { recovered } \\
\left(\mu \mathrm{g} \cdot \mathrm{L}^{-1}\right)\end{array}$ & $\begin{array}{c}\mathrm{RSD} \\
(\%)\end{array}$ & $\begin{array}{c}\text { Recovery } \\
(\%)\end{array}$ \\
\hline \multirow{3}{*}{$\begin{array}{c}\text { Well } \\
\text { water }\end{array}$} & 0 & 2.2920 & - & - & 0.8 & - \\
& 20.00 & 0.5194 & 21.7726 & 19.4806 & 0.9 & 97.4 \\
& 40.00 & 2.0130 & 40.2790 & 37.9870 & 1.1 & 95.0 \\
\hline \multirow{2}{*}{$\begin{array}{c}\text { River } \\
\text { water }\end{array}$} & 0 & 1.7070 & - & - & 0.9 & - \\
& 40.00 & 0.3246 & 21.3824 & 19.6754 & 0.6 & 98.4 \\
Tap & 0 & 2.1428 & 39.5642 & 37.8572 & 1.0 & 94.6 \\
water & 20.00 & 0.7404 & - & - & 0.6 & - \\
& 40.00 & 3.4416 & 37.2988 & 36.5584 & 1.1 & 91.4 \\
\hline
\end{tabular}

The results show that the recoveries of $\mathrm{Cu}^{2+}$ are $91.4 \% \sim 98.4 \%$, and the RSD is $0.6 \% \sim 1.2 \%$.

\section{Conclusion}

In this paper,a novel method for the spectrophotometric determination of trace $\mathrm{Cu}^{2+}$ after flotation separation using sodium chloride- ammonium thiocyanate-dodecyl dimethyl benzyl ammonium chloride system was reported. The proposed method has been successfully used for the determination of trace $\mathrm{Cu}^{2+}$ in various water samples with satisfactory results. It was obvious that this study had certain practical significance on establishing a new methods of separation and determination of trace copper.

\section{Acknowledgement}

This work was financially supported by the Guangdong Science and Technology Project (2012A030700007) and Guangdong Nature Science Foundation(S2012010010978). 


\section{References}

[1] Taskaev,E.;Penev,I.;Kinova,L. J.Radioanal.Nucl.Chem.1988,12(1),83.

[2] Alonso,A.; Almendral,M.-J.; Curto,Y.; Porras,M.-J. Microchim. Acta.2003, 143, 217.

[3] Wei,G.-T.; Chen,J.-C.; Yang,Z. J.Chin. Chem. Soc. 2003, 50, 1123.

[4] Nuray, S.; Cigdem,A. Microchim. Acta.2008, 162, 107.

[5] Ghaedi,M.; Shokrollahi,A.; Niknam,K.; Niknam,E.; Soylak,M. Cent. Eur. J. Chem. 2009, 7(1) , 148.

[6] Sakai,Y.; Tomura,T.; Ohshita,K.; Koshimizu,S. J. Radioanal. Nucl. Chem.1998, 230(1- 2 ), 261.

[7] Romero,R.; Jonsson,J.-A. Anal. Bioanal. Chem. 2005, 381, 1452.

[8] Prakorn,R.; Kwanta,N.; Ura,Pancharoen. Korean J. Chem. Eng.2004, 21(6), 1212.

[9] Konar,B.; Basu,S. Fresenius J. Anal. Chem.1994,348,281.

[10] Khuhawar,M.-Y.; Lanjwani,S-N. Mikrochim. Acta.1998, 129, 65.

[11] Väisänen,A.; Suontamo,R.; Silvonen,J.; Rintala,J. Anal.Bioanal.Chem.2002, 373,93.

[12] Hu,Q.-F.; Yang,G.-Y.; Zhao,Y.-Y.; Yin,J.-Y. Anal.Bioanal.Chem.2003, $375,831$.

[13] Guo,J.-J.;Su,Q-D.;Gan,W.-E. J.Chin. Chem. Soc.2009, 56, 763.

[14] Chang,W.-B.;Li,K.-A.Brief Handbook of Analytical Chemistry;Beijing University Press:Beijing, 1981;a 240,b 262. (in Chinese)

[15] Pan,J.-M.;Chen,Y.-S.;Yan,H.-T. Chromogenic Agent and Its Application in Metallurgical Analysis; Shanghai Scientific and Technical Publisher :Shanghai, 1981,116. (in Chinese) 